\title{
Maintenance of ATP favours apoptosis over necrosis triggered by benzamide riboside
}

M Grusch ${ }^{1}$, D Polgar ${ }^{1}$, S Gfatter ${ }^{2}$, K Leuhuber ${ }^{3}$, S Huettenbrenner ${ }^{1}, \mathrm{C}$ Leisser ${ }^{1}, \mathrm{G}$ Fuhrmann ${ }^{1}, \mathrm{~F}$ Kassie $^{2}$, H Steinkellner ${ }^{2}, \mathrm{~K} \mathrm{Smid}^{4}$, GJ Peters ${ }^{4}$, HN Jayaram ${ }^{5}$, W Klepal ${ }^{3}$, T Szekeres ${ }^{6}$, S Knasmüller ${ }^{2}$ and G Krupitza*,1

1 Institute of Clinical Pathology, University of Vienna, Austria

2 Institute for Cancer Research, University of Vienna, Austria

${ }^{3}$ Institute of Zoology, University of Vienna, Austria

${ }^{4}$ Department of Medical Oncology, University Hospital VU Amsterdam, The Netherlands

${ }^{5}$ Department of Biochemistry and Molecular Biology and Laboratory for Experimental Oncology, Indiana University School of Medicine, Indianapolis, USA

${ }^{6}$ Clinical Institute of Medical and Chemical Laboratory Diagnosis, University of Vienna, Austria

* Corresponding author: G Krupitza, Institute of Clinical Pathology, Waehringer Guertel 18-20, A-1090 Vienna, Austria. Tel: 0043140400 3487; Fax: 00431 40534 02; E-mail: g.krupitza@akh.wien.ac.at

Received 6.6.01; revised 31.7.01; accepted 1.8.01

Edited by RA Knight

\section{Abstract}

A new synthetic drug, benzamide riboside (BR) exhibited strong oncolytic activity against leukemic cells in the 5-10 $\mu \mathrm{M}$ range. Higher BR-concentrations $(20 \mu \mathrm{M})$ predominantly induced necrosis which correlated with DNA strand breaks and subsequent depletion of ATP- and dATP levels. Replenishment of the ATP pool by addition of adenosine prevented necrosis and favoured apoptosis. This effect was not a pecularity of BR-treatment, but was reproduced with high concentrations of all trans-retinoic acid $(120 \mu \mathrm{M})$ and cyanide (20 mM). Glucose was also capable to suppress necrosis and to favour apoptosis of HL-60 cells, which had been treated with necrotic doses of BR and cyanide. Apoptosis eliminates unwanted cells without affecting the microenvironment, whereas necrosis causes severe inflammation of surrounding tissues due to spillage of cell fluids into the peri-cellular space. Thus, the monitoring and maintenance of cellular energy pools during therapeutic drug treatment may help to minimize nonspecific side effects and to improve attempted drug effects.

Cell Death and Differentiation (2002) 9,169-178. DOI: 10.1038/sj/ $\mathrm{cdd} / 4400937$

Keywords: benzamide riboside; apoptosis; necrosis; ATP

Abbreviations: ATP, adenosine triphosphate; ATRA, all-trans retinoic acid; BR, 3-(1- $\beta$-D-ribofuranosyl)benzamide or benzamide riboside; dATP, 2'-deoxyadenosine 5'-triphosphate; dGTP, 2'deoxyguanosine 5 '-triphosphate; DTT, DL-dithiothreitol; EDTA, ethylenediaminetetraacetic acid; FCS, foetal calf serum; GTP, guanosine $5^{\prime}$-triphosphate; IMP, inosine $5^{\prime}$-monophosphate; IMPDH, inosine 5'-monophosphate dehydrogenase; HO, Hoechst 33258; KCN, potassium cyanide; NAD, nicotinamide adenine dinucleotide; PARP, poly(ADP-ribose)polymerase; PBS, phosphate-buffered saline; PI, propidium iodide; RR, ribonucleotide reductase; SCGE, single cell gel electrophoresis or comet assay; SDS, sodium dodecyl sulfate; TCA, trichloro acetic acid; TEM, transmission electron microscopy; TR, 2- $\beta$-D-ribofuranosylthiazole4-carboxamide or tiazofurin; XMP, xanthosine $5^{\prime}$-monophosphate

\section{Introduction}

Benzamide riboside (BR) is a C-nucleoside ${ }^{1}$ that has recently been characterised as an inosine $5^{\prime}$-monophosphate dehydrogenase (IMPDH)-inhibitor. ${ }^{2,3}$ This enzyme catalyses the conversion of IMP to xanthosine $5^{\prime}$-monophosphate (XMP) and is the rate limiting enzyme in de novo guanylate biosynthesis. ${ }^{4}$ The activity of this enzyme is significantly increased in tumour cells and therefore considered to be a potential target for cancer chemotherapy. ${ }^{5}$ Tiazofurin (TR), which is metabolized in a similar manner to that of BR, was found to inhibit the growth of human myelogenous leukaemia $\mathrm{K} 52^{6}$ and human promyelocytic leukaemia $\mathrm{HL}-60$ cells. ${ }^{7}$ TR is an inhibitor of $\mathrm{IMPDH}^{8}$ and Phase $\mathrm{I} / \mathrm{Il}$ clinical trials conducted with this compound in acute myelogenous leukaemia patients, indicated a significant reduction in leukaemic cell burden. ${ }^{9-11} \mathrm{BR}$, exhibited stronger antiproliferative activity in the K562 cells than TR ${ }^{12}$ and was shown to induce apoptosis in $\mathrm{HL}-60^{13}$ and $\mathrm{N} .1$ ovarian carcinoma cells. ${ }^{13,14}$ Higher BR-concentrations however, provoked necrosis, which is a common phenomenon of pro-apoptotic drugs ${ }^{15-17}$ and limits chemotherapy because of non-specific drug toxicity. Overdosing results in necrosis and spilling of intracellular fluids into the peri-cellular space, leading to inflammatory responses with wide ranging destructions of surrounding tissues. Therefore it is of prime interest to develop strategies to suppress necrosis and favour apoptosis. Interestingly, both cell death modes, apoptosis and necrosis, were discussed to partly share similar early pathways. ${ }^{17-19}$

It was postulated that BR exerts its anti-tumour effects due to IMPDH inhibition. ${ }^{2,12}$ Therefore dGTP and other dNTP levels were analyzed and correlated with cell death modes. The necrotic trigger of high BR-concentrations was identified as DNA-clastogenic activity, which subsequently led to ATP depletion. It is likely that ATP levels are the key factor deciding the death modes, because apoptosis is energy- (ATP-) dependent, whereas necrosis is not. Here we describe a new strategy to reduce non-specific toxicity by drug-overload, by artificially keeping ATP levels high and to specifically promote apoptosis and prevent necrosis. 


\section{Results}

\section{The BR concentrations determines the type of cell death}

Treatment of HL-60 cells with increasing doses of BR induced cell death which was analyzed by Trypan blue staining (data not shown). ${ }^{20}$ To further discriminate the type of cell death, the integrity of poly(ADP-ribose) polymerase [PARP] and gelsolin was examined by Western blotting (Figure 1). PARP and Gelsolin become signature-specifically fragmented by Caspase 3 upon induction of apoptosis. Addition of $0.5 \mu \mathrm{M}, 1 \mu \mathrm{M}$, or $2 \mu \mathrm{M}$ BR neither induced cell death nor gelsolin cleavage, whereas concentrations of $5 \mu \mathrm{M}$ or $10 \mu \mathrm{M}$ BR caused apoptosis which was evidenced by degradation of gelsolin into a $41 \mathrm{kD}$ fragment $^{21}$ and of PARP into a $89 \mathrm{kD}$ fragment (Figure 1a,b). Further increase of the BR-concentrations to $20 \mu \mathrm{M}$ led to an increase of the fraction of necrotic cells and reduced the fraction of apoptotic cells, which was also reflected by the lack of PARP and gelsolin fragmentation.

$\mathrm{HL}-60$ cells treated with $5 \mu \mathrm{M}$ BR or $20 \mu \mathrm{M}$ BR for $24 \mathrm{~h}$ exhibited typical apoptotic or necrotic morphologies, respectively, which was examined by electron microscopy (Figure 2). The untreated control cell (Figure 2a) was characterised by an intact cell membrane and nuclear envelope and a normal chromatin distribution. HL-60 cells treated with $5 \mu \mathrm{M}$ BR (Figure 2b) still maintained intact membranes but electron dense chromatin marginated at the nuclear envelope as a hallmark of apoptosis. The vacuoles

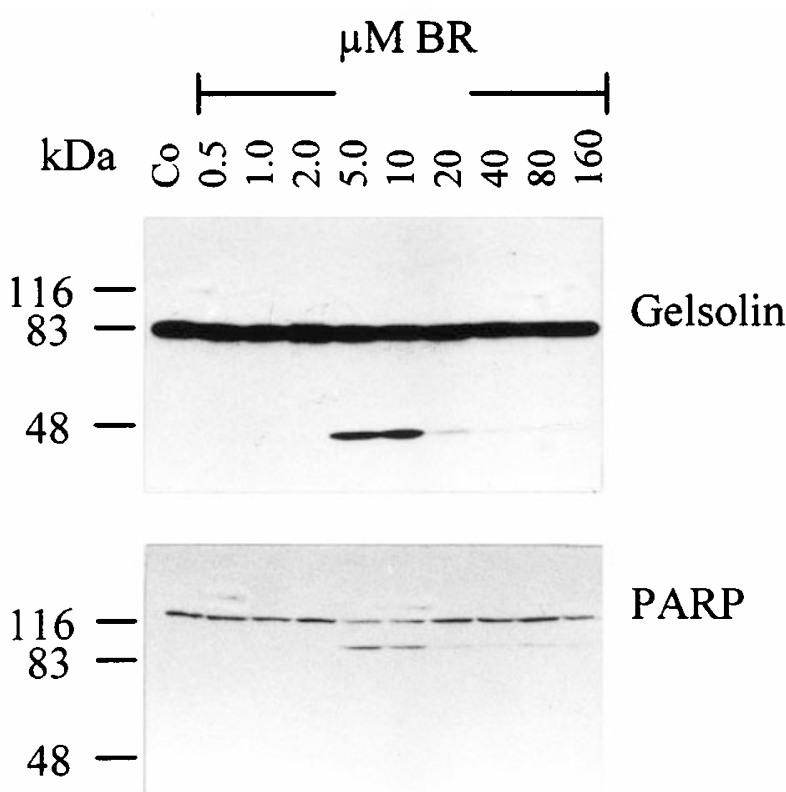

Figure 1 Cleavage of the caspase substrate poly(ADP-ribose) polymerase (PARP) (A) and gelsolin (B) following treatment of HL-60 cells with increasing doses of $B R$. Controls were treated with saline for $24 \mathrm{~h}$ and Western blots were performed as described in Materials and Methods. The $89 \mathrm{kD}$ cleavage product of PARP and the $41 \mathrm{kD}$ cleavage product of gelsolin could be detected upon treatment with $5 \mu \mathrm{M}$ and $10 \mu \mathrm{M}$ BR and diminished in response to higher doses of BR
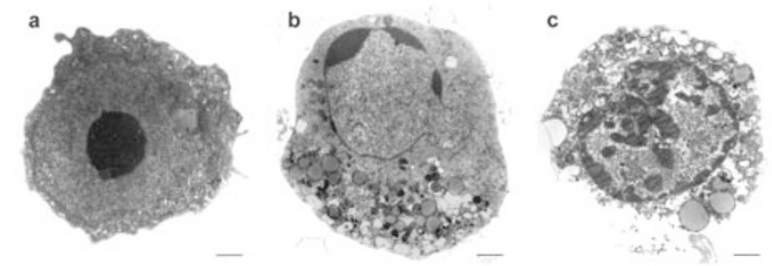

Figure 2 Electron microscopical images of apoptotic and necrotic HL-60 cells. HL-60 cells were treated with saline (A), $5 \mu \mathrm{M} \mathrm{BR}$ (B), and $20 \mu \mathrm{M} \mathrm{BR}$ (C) for $24 \mathrm{~h}$, and prepared for electron microscopoical analysis as described in Materials and Methods. Panel A shows an intact cell morphology, panel B an apoptotic cell with typical DNA condensation and margination at the nuclear envelope and panel $\mathrm{C}$ a necrotic cell exhibiting cloudy chromatin and destructed organelles and membranes. The bars at the lower right corners indicate $1.1 \mu \mathrm{m}$

in the cytoplasm seemed to enlarge during BR treatment. HL-60 cells treated with $20 \mu \mathrm{M}$ BR (Figure 2c) exhibited typical necrotic morphology such as disrupted membranes and cloudy chromatin.

\section{Measurement of dNTP- and ATP-levels}

The dNTP levels were determined after $16 \mathrm{~h}$ treatment. At this time point cells were still viable and membranes intact, preventing nonspecific loss of dNTPs. ${ }^{22}$

Table 1 shows that $5 \mu \mathrm{M}$ BR and $20 \mu \mathrm{M}$ BR repressed dGTP levels to similar extent (approximately 53\% of control). The cellular dGTP concentrations did not correlate with induction of apoptosis or necrosis by $5 \mu \mathrm{M}$ BR and $20 \mu \mathrm{M}$ BR respectively, after 16,24 or $48 \mathrm{~h}$ of treatment (compare with Figure 3a). Whereas dCTP (89\% of control) - and dATP ( $81 \%$ of control) - levels were in the range of control when cells were treated with $5 \mu \mathrm{M}$ BR, exposure to $20 \mu \mathrm{M}$ BR caused a drop in dCTP and dATP levels to 37 and $33 \%$, respectively.

It was assumed that ATP level is a determinant of cell death modes. ${ }^{15,23-25}$ Hence, we determined the ATP levels in HL-60 cells (Figure $3 \mathrm{~b}$ ) after treatment with $5 \mu \mathrm{M}$ BR (which causes apoptosis) and after exposure to $20 \mu \mathrm{M}$ BR (which mainly causes necrosis) (Figure $3 a$ ). In case ATP determines the type of cell death, then it has to be a regulatory parameter before cell death (apoptosis and/or necrosis) occurs. Therefore, the intracellular ATP pools were examined after $16 \mathrm{~h}$ of treatment (Figure $3 \mathrm{~b}$ ), when the cell membranes were still intact and no non-specific loss of nucleotides took place. Treatment with a membrane permeable ATP-precursor, adenosine, was expected to replenish the intracellular pools of ATP and to inhibit necrosis. In fact, addition of $800 \mu \mathrm{M}$ adenosine rescued the ATP levels in $20 \mu \mathrm{M}$ BR treated cells to $31 \%$ of the control value, whereas a dramatic ATP drop to $2.7 \%$ of control was seen, when cells were exposed to $20 \mu \mathrm{M}$ BR only (Figure $3 b)$. In the adenosine-treated cells necrosis was indeed inhibited (Figure 3a). Figure $3 \mathrm{c}$ shows HOPI double-stained viable cells, early and late apoptotic cells and necrotic HL-60 cells, which were exposed to $5 \mu \mathrm{M}$ and $20 \mu \mathrm{M}$ BR, with or without adenosine (panel A). For reasons of comparison, panel B depicts necrotic HL-60 cells which 
Table 1 dNTP levels in response to treatment of HL-60 cells with benzamide riboside

\begin{tabular}{|c|c|c|c|c|c|}
\hline HL-60 & dATP & dTTP & dCTP & dGTP & Apoptosis \\
\hline $\begin{array}{l}\text { Control } \\
(100 \%)\end{array}$ & $\begin{array}{c}10.6 \mathrm{pm} \\
(+1.0,-0.7)\end{array}$ & $\begin{array}{c}18.2 \mathrm{pm} \\
(+7.9,-5.1)\end{array}$ & $\begin{array}{c}9.1 \mathrm{pm} \\
(+1.0,-1.9)\end{array}$ & $\begin{array}{c}9.1 \mathrm{pm} \\
(+1.8,-1.2)\end{array}$ & $1 \%$ \\
\hline $\begin{array}{l}5 \mu \mathrm{M} \text { BR } \\
20 \mu \mathrm{M} \text { BR } \\
\text { Co+A } \\
5 \mu \mathrm{M} \text { BR+A } \\
20 \mu \mathrm{M} B R+A\end{array}$ & $\begin{array}{l}81.3 \% \\
32.6 \% \\
69.9 \% \\
76.1 \% \\
65.1 \% \\
\end{array}$ & $\begin{array}{l}252.1 \% \\
148.4 \% \\
113.6 \% \\
327.8 \% \\
177.7 \%\end{array}$ & $\begin{array}{r}89.5 \% \\
36.7 \% \\
64.3 \% \\
117.1 \% \\
58.4 \%\end{array}$ & $\begin{array}{l}52.6 \% \\
53.8 \% \\
39.8 \% \\
29.5 \% \\
29.6 \% \\
\end{array}$ & $\begin{array}{r}4 \% \\
18 \% \\
9 \% \\
11 \% \\
7 \%\end{array}$ \\
\hline
\end{tabular}

HL-60 cells were treated with increasing doses of benzamide riboside (BR) for $16 \mathrm{~h}$. Then the cells were lysed, and dNTPs isolated and analyzed as described in Materials and Methods. Values are given in picomol (pm) of each dNTP per $1 \times 10^{6}$ cells for controls, and as per cent of control for treated samples

underwent heat shock treatment $\left(55^{\circ} \mathrm{C}\right)$ for increasing times and panel $\mathrm{C}$ demonstrates the lack of PARP cleavage after heat shock (Figure 3c). Re-directing necrosis to apoptosis was also reflected by Caspase 3 cleavage to its active form in presence of $800 \mu \mathrm{M}$ adenosine in HL-60 cells which were treated with $20 \mu \mathrm{M}$ BR (Figure 3d). Whereas Caspase 3 activation culminated (p20 kD fragment) after exposure to $5 \mu \mathrm{M}$ and $10 \mu \mathrm{M}$ BR after $24 \mathrm{~h}$, activation was inhibited after exposure to $20 \mu \mathrm{M}$ or $40 \mu \mathrm{M}$ BR. In contrast, more of the activated Caspase 3-fragment was detected after $20 \mu \mathrm{M}$ and $40 \mu \mathrm{M}$ BR-treatment in presence of $800 \mu \mathrm{M}$ adenosine. Lower adenosine levels had no effect probably due to limits in cellular uptake or due to specific degradation by adenosine deaminase.

\section{ATP-, dATP-, and dCTP-levels correlate with apoptosis}

To elucidate, whether a direct correlation exists between nucleotide pools and death modes, ATP, dATP and dCTP levels were plotted in combination with the corresponding apoptosis- and necrosis-rates. For improved comprehension we summarised in Table 2 the ATP-, dATP-, dCTP-levels and death data and graphically compared the inter-relationships of total cell deaths, the apoptotic- and the necrotic subtypes with nucleotide levels from differently treated cells. It can be seen in Figure $4 a, b$ and $c$ that ATP-, dATP-, and dCTP levels directly correlate with apoptosis rates and inversely with the necrosis rates, when cell death was induced by BR (not however in non-induced cells such as control or adenosine control; not shown in Figure $4 a-c)$. There was no correlation of ATP or dATP levels with total cell deaths (apoptosis+ necrosis; not shown).

Apoptosis is an energy dependent process, because to maintain membrane integrity ATP is required. Since adenosine restored the ATP pool and prevented necrosis also glucose was anticipated to prevent necrosis ${ }^{18,25-27}$ and to determine death modes. In fact $100 \mathrm{mM}$ glucose nearly completely inhibited necrosis of HL-60 cells induced by treatment with $20 \mu \mathrm{M}$ BR and instead favoured apoptosis, which was determined by HOPI double-staining. ${ }^{13,22,28}$ In these experiments spontaneous cell death of controls exhibited an apoptosis: necrosis-ratio $A: N=3.6: 1.20 \mu \mathrm{M} B R$ resulted in a ratio $A: N=1: 3.4$, which was converted by the addition of glucose to a ratio $A: N=7.8: 1$.

\section{Adenosine prevents ATRA- and KCN-triggered necrosis in favour of apoptosis}

To examine, whether prevention of necrosis by energy donors was a peculiarity of BR-induced cell death, or it represents a more general mechanism, HL-60 cells were treated with alltrans retinoic acid (ATRA) and potassium cyanide (KCN). ATRA is used clinically to treat acute promyeloic leukaemia. ${ }^{29}$ $\mathrm{KCN}$ blocks the respiratory chain and prevents ATP generation. ${ }^{30-32}$ Exposure of the cells to $120 \mu \mathrm{M}$ ATRA for $48 \mathrm{~h}$ resulted in $30 \%$ apoptotic and $45 \%$ necrotic cells (apoptosis: necrosis ratio $\mathrm{A}: \mathrm{N}=1: 1.5)$ (Figure 5). Addition of $100 \mathrm{mM}$ glucose repressed both apoptosis and necrosis $(\mathrm{A}: \mathrm{N}=1: 1.2)$. Also $800 \mu \mathrm{M}$ adenosine repressed both types of cell death, but in this case the apoptosis rate was increased $(A: N=1.8: 1)$. The effect of glucose and adenosine on $\mathrm{KCN}$ induced cell death was even more dramatic: $20 \mathrm{mM} \mathrm{KCN}$ alone caused $32 \%$ apoptosis and $41 \%$ necrosis after $48 \mathrm{~h}$ of treatment $(\mathrm{A}: \mathrm{N}=1: 1.3)$ in $\mathrm{HL}-60$ cells. Addition of $100 \mu \mathrm{M}$ glucose did not suppress $\mathrm{KCN}$-induced cell death, as in the case with ATRA, and inverted the death ratio in favour of $61 \%$ apoptosis $(\mathrm{A}: \mathrm{N}=1.7: 1) .800 \mu \mathrm{M}$ adenosine substantially suppressed necrosis and increased the apoptosis rate to $43 \%(A: N=9.1: 1)$ (Figure 5).

\section{Necrotic BR-concentrations induce DNA double-strand breaks}

DNA integrity was measured in individual cells with the single cell gel electrophoresis (comet) assay. The analyses were performed at time points (8 and $16 \mathrm{~h}$ of treatment with $\mathrm{BR}$ ), when the cell membranes were still intact and before apoptotic or necrotic markers were observed, but when ATP- and dNTP-pools were already affected. The results of comet assays performed at neutral $\mathrm{pH}$ (7.5) showed that $20 \mu \mathrm{M}$ BR, but not $5 \mu \mathrm{M}$ BR, induced DNA double-strand breaks within $8 \mathrm{~h}$ of treatment. These breaks were efficiently repaired after $16 \mathrm{~h}$ (Figure 6a). Additional comet-analyses at alkaline $\mathrm{pH}$ (13.0) demonstrated also that DNA single-strand breaks occurred after incubation with $20 \mu \mathrm{M} \mathrm{BR}$, but not with $5 \mu \mathrm{M}$ BR treatment. These lesions were substantially, but not completely repaired after $16 \mathrm{~h}$ (Figure 6b). The ATP level after $16 \mathrm{~h}$ of treatment with $20 \mu \mathrm{M}$ BR (3\% control) seemed to be insufficient for the repair of the remaining DNA singlestrand breaks, and this might have resulted in necrosis. These results also suggest that $5 \mu \mathrm{M}$ BR-induced apoptosis 
is not causally related to DNA double- or single-strand breaks.

Viable and pre-apoptotic cells contain (relatively) high ATP levels in contrast to pre-necrotic cells. Therefore, we compared cells with high versus low ATP content with the extent of DNA damage after $16 \mathrm{~h}$ of treatment. Comet analysis at alkaline $\mathrm{pH}$ (13.0) revealed that the combined percentage of surviving+apoptotic cells $(98 \%$ of the cells after each exposure to either $5 \mu \mathrm{M}$ BR or $5 \mu \mathrm{M}$ BR+adenosine) corresponded to a $25 \mu \mathrm{m}$ DNA tail length (96 and 95\%, respectively, see Table 2). Whereas the percentage of necrotic cells (51\% after treatment with $20 \mu \mathrm{M} \mathrm{BR})$ correlated with cells with a $>25 \mu \mathrm{m}$ DNA tail length (50\%) (Table 2, Figure 6b). The inclusion of adenosine promoted DNA repair of a subset of $20 \mu \mathrm{M}$ BR-treated cells after $16 \mathrm{~h}$. However, in $26 \%$ of the $20 \mu \mathrm{M}$ BR-damaged cells DNA-single-strand breaks also accumulated after $16 \mathrm{~h}$ when co-treated with adenosine, because DNA tail lengths increased $(100-140 \mu \mathrm{m})$ (Figure 6b). The combined percentages (68\%; viable+apoptotic) of $20 \mu \mathrm{M}$ BR+adenosine treated cells did not correlate with the percentage of cells with a DNA tail length $<25 \mu \mathrm{m}(45 \%)$ (Table 2, Figure $6 b)$. This demonstrates that adenosine allowed $\sim 23 \%$ of the cells, which still had substantially damaged DNA and that were otherwise prone for necrosis (DNA tail length $>25 \mu \mathrm{m},<87 \mu \mathrm{m})$, to undergo apoptosis.

\section{3-amino benzamide (3-AB) represses necrosis}

Since $20 \mu \mathrm{M}$ BR dramatically depleted the ATP pool to $3 \%$ of control we speculated that this might have been due to DNA strand break-dependent activation of poly(ADP-ribose)polymerase (PARP). PARP consumes NAD and in consequence also affects the ATP pool. ${ }^{33,34}$ Moreover, PARP activity was shown to provoke necrosis ${ }^{23,35,36}$ and in $\operatorname{PARP}(-/-)$ mice upon cerebral ischemia reperfusion necrotic cell death did not occur. $^{37} 3-A B$ is a potent inhibitor of PARP, and in fact, we found that $20 \mu \mathrm{M}$ BR-induced necrosis was inhibited in presence of $2 \mathrm{mM} 3-\mathrm{AB}$ (Figure 7). This supports the assumption that PARP-activation might provoke BR-induced necrosis due to energy depletion, which is prevented by PARP-inhibition.

\section{Discussion}

It is a well known phenomenon that cytotoxic drugs, which can induce apoptosis, promote necrosis when administered at higher concentrations. ${ }^{15-17,38}$ Several reports suggest that apoptosis and necrosis share, in part, similar (early) pathways of induction. ${ }^{17-19,39}$ Also p53 might determine whether a death pathway can be completed by apoptosis or whether mutated p53 allows only for a necrotic fate at equitoxic concentrations.

It was suggested that the intracellular ATP level determines whether a cell dies in an apoptotic or necrotic mode. ${ }^{15,23-25}$ Therefore, we investigated ATP levels in benzamide riboside (BR)-treated HL-60 cells, which apoptosed after $5 \mu \mathrm{M}$ treatments, whereas they underwent necrosis at $20 \mu \mathrm{M}$ BR treatment. BR is a new synthetic Cnucleoside, ${ }^{1}$ which inhibits IMPDH, the rate limiting enzyme of de novo guanylate biosynthesis. IMPDH is frequently overexpressed in cancer cells and therefore, considered a target for anti-tumour therapy. It was previously demonstrated that BR exhibits strong anti neoplastic activity in a panel of human tumour cell lines ${ }^{3}$ and was most effective in leukaemia cells by inducing apoptosis. ${ }^{13,14,40}$ The oncolytic activity of $\mathrm{BR}^{3}$ was assumed to be due to its IMPDH-inhibitory and, therefore, dGTP-limiting action. ${ }^{2,12}$ This hypothesis was strongly encouraged by the observation, that guanosine, a precursor of dGTP, prevented the oncolytic activity of BR. ${ }^{12,41}$

Our findings show, that $5 \mu \mathrm{M}$ BR induced apoptosis, whereas $20 \mu \mathrm{M}$ BR provoked necrosis, although both concentrations of BR inhibited dGTP synthesis to a similar degree. dGTP levels were comparably affected by adenosine, which only marginally interfered with cell survival (see Table 2). Therefore, it seems unlikely that dGTP depletion alone accounted for the cell death mechanism elicited by BR. BR-mediated limitation of dGTP a

\section{Cell death induction by benzamide riboside and modulation by adenosine}

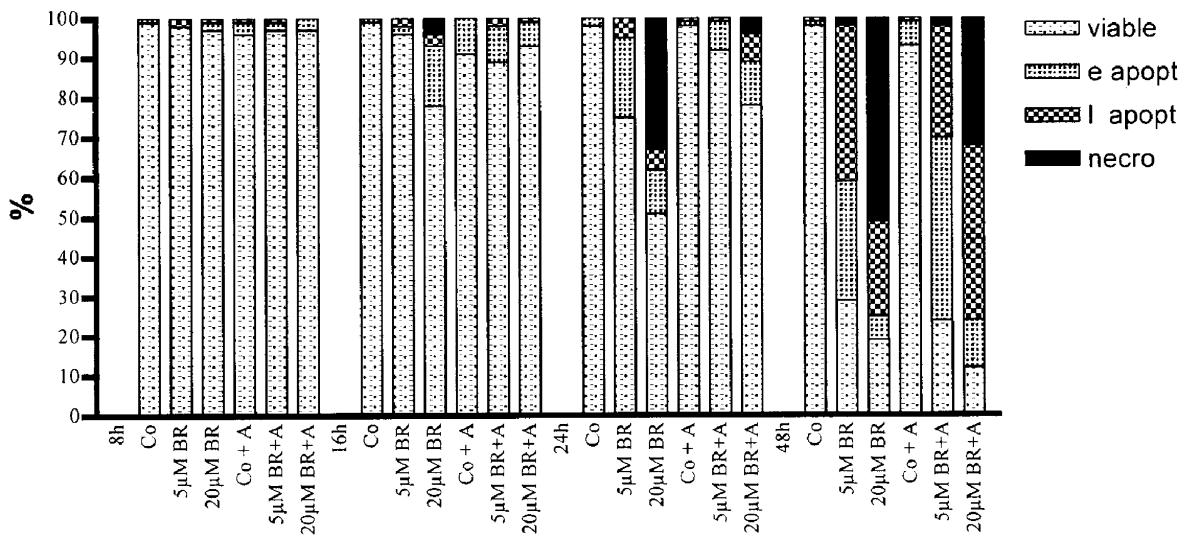

b

ATP level in BR

(+/- adenosine)- treated HL-60 cells

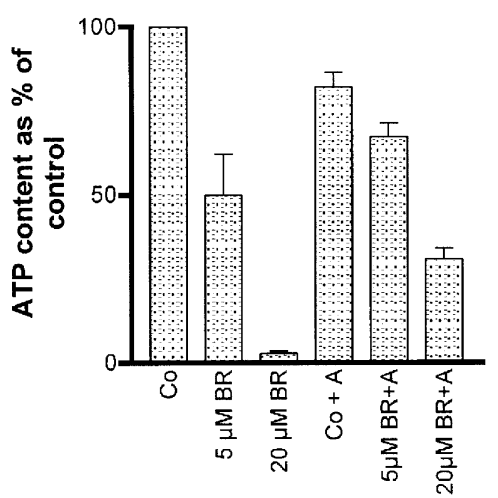


Table 2 Comparison of dNTP levels with DNA tail lengths and cell status

\begin{tabular}{|c|c|c|c|c|c|c|c|c|c|}
\hline & $\begin{array}{c}\% \\
\text { ATP }\end{array}$ & $\begin{array}{c}\% \\
\text { dATP }\end{array}$ & $\begin{array}{c}\% \\
\text { dCTP }\end{array}$ & $\begin{array}{l}\text { DNA tail } \\
\text { length }\end{array}$ & $\begin{array}{c}\% \\
\text { viable }\end{array}$ & $\begin{array}{c}\% \\
\text { apopt }\end{array}$ & $\begin{array}{c}\% \text { viable } \\
\text { +apopt }\end{array}$ & $\begin{array}{c}\% \\
\text { necro }\end{array}$ & $\begin{array}{l}\% \text { total } \\
\text { death }\end{array}$ \\
\hline Control & 100 & 100 & 100 & $98 \%<=25 \mu \mathrm{m}$ & 98 & 2 & 100 & 0 & 2 \\
\hline Ade & 85 & 70 & 64 & $98 \%<=25 \mu \mathrm{m}$ & 93 & 7 & 100 & 0 & 7 \\
\hline $5 \mu \mathrm{M}$ BR & 50 & 81 & 89 & $96 \%<=25 \mu \mathrm{m}$ & 29 & 69 & 98 & 2 & 71 \\
\hline $20 \mu \mathrm{M}$ BR & 3 & 33 & 37 & $\begin{array}{l}50 \%<=25 \mu \mathrm{m} \\
50 \%>=25 \mu \mathrm{m}\end{array}$ & 19 & 30 & 49 & 51 & 81 \\
\hline $5 \mu \mathrm{M} \mathrm{BR+Ade}$ & 68 & 76 & 117 & $95 \%<=25 \mu \mathrm{m}$ & 24 & 74 & 98 & 2 & 76 \\
\hline $20 \mu \mathrm{M}$ BR+Ade & 31 & 56 & 58 & $\begin{array}{l}45 \%<=25 \mu \mathrm{m} \\
55 \%>=25 \mu \mathrm{m}\end{array}$ & 12 & 56 & 68 & 32 & 88 \\
\hline
\end{tabular}

The percentages of ATP, dATP and dCTP levels and the DNA tail length of HL-60 cells after $16 \mathrm{~h}$ of BR \pm adenosine treatment, and the percentages of viable, apoptotic and necrotic cells following treatment for $48 \mathrm{~h}$ with $\mathrm{BR} \pm$ adenosine, were measured. Viable cells displayed nuclei homogeneously stained with Hoechst and excluded PI. Apoptotic cells showed chromatin condensation and nuclear fragmentation. At least 200 cells were counted from each sample

c

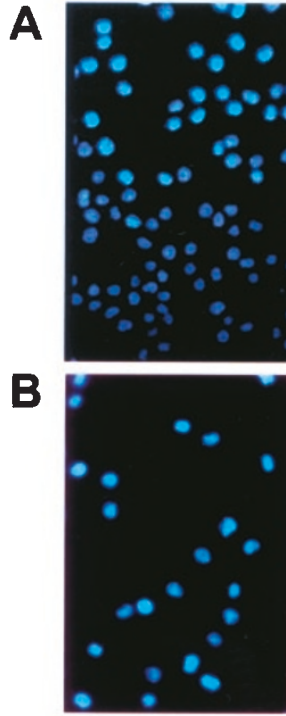

Co
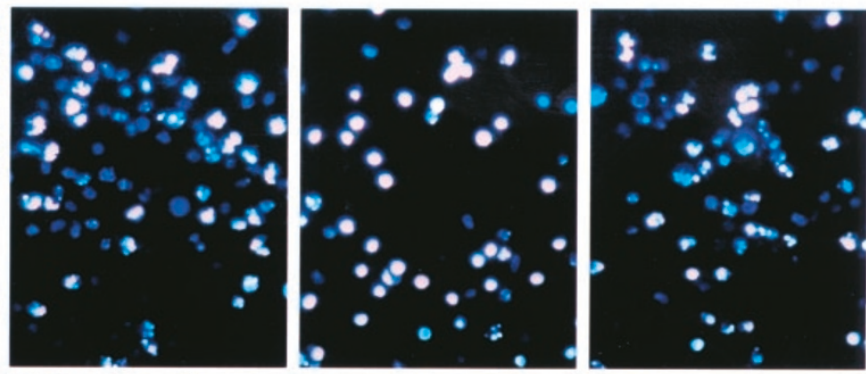

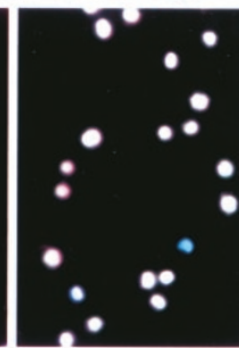

$1 \mathrm{~h}$

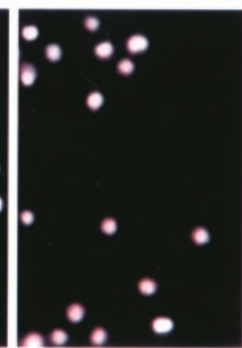

$3 h$

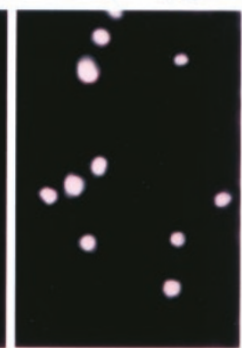

$5 h$

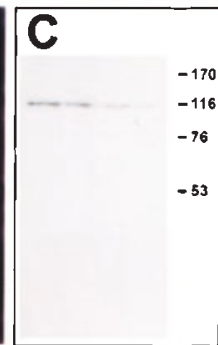

Co $1 \mathrm{~h} 3 \mathrm{~h} 5 \mathrm{~h}$

d

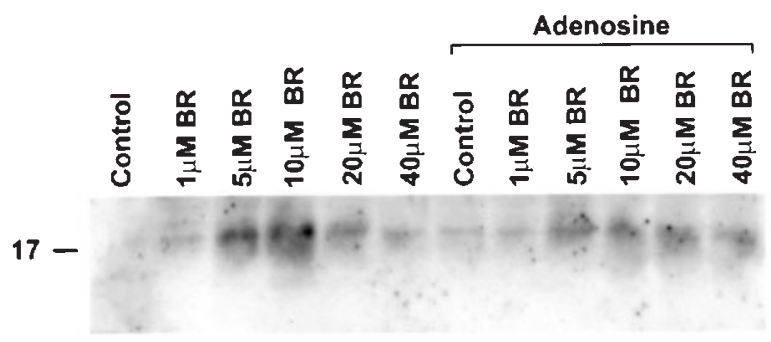

Figure 3 Induction of cell deaths modes by BR. (a) Cells were treated with saline (Co), $800 \mu \mathrm{M}$ adenosine $(\mathrm{C} 0+\mathrm{A}), 5 \mu \mathrm{M}$ BR $( \pm \mathrm{adenosine}), 20 \mu \mathrm{M} B R$ ( \pm adenosine) for $8,16,24$ and $48 \mathrm{~h}$. Then cells were harvested and stained with HO/PI, applied on glass slides, allowed to settle to the surface and then cells were counted under a microscope using a DAPI filter and cell death was determined. "e apopt": early apoptotic cells; "I apopt": late apoptotic cells; "necro": necrotic cells. Statistical analysis by $t$-test confirmed that the differences between apoptosis- and necrosis-rates after treatment with BR ( \pm adenosine) for $48 \mathrm{~h}$ were significant $(P<0.05)$. (b) Cells were treated with saline (Co), adenosine $(\mathrm{A}), 5 \mu \mathrm{M}$ and $20 \mu \mathrm{M}$ BR ( \pm adenosine) for $16 \mathrm{~h}$, which was a time point at which cellular membranes were still intact to avoid leaking. Then cells were harvested and the intracellular ATP content was measured as described in 'Methods'. Statistical analysis by $t$-test confirmed that the differences between ATP-levels after treatment with $\mathrm{BR}$ ( \pm adenosine) were significant $(P<0.05)$. (c) Micrographs of $\mathrm{HL}-60$ cells stained with Hoechst $33258(\mathrm{HO})$ and propidium iodide (PI) after treatment with saline, $5 \mu \mathrm{M} \mathrm{BR}, 20 \mu \mathrm{M} \mathrm{BR}$, and $20 \mu \mathrm{M}$ BR+800 $\mu \mathrm{M}$ adenosine (panel A) for $48 \mathrm{~h}$ (1st, 2nd, 3rd and 4th slides, from left to right, respectively). Panel B shows HL-60 cells which were exposed to $55^{\circ} \mathrm{C}$ heat shock for increasing times. The nuclei of viable cells stain blue (the cytoplasm remains invisible). In an early phase of apoptosis condensed chromatin is visible as small round bodies which usually stain more intense blue with HO. Late apoptotic cells exhibit similar chromatin condensation but the colour shifts to pink due to PI intrusion through leaky membranes as a consequence of apoptosis progression. Upon $20 \mu \mathrm{M}$ BR treatment, or in response to heat shock, increasing numbers of cells show a pink colour but lack apoptotic (condensed) chromatin (necrotic cells). Panel C: $\mathrm{HL}-60$ cells were exposed to heat shock treatment (55 ${ }^{\circ} \mathrm{C}$ ) for 1,3 and $5 \mathrm{~h}$ and PARP expression and degradation was monitored by Western blotting. There is no apoptosis specific cleavage of PARP into the $89 \mathrm{kD}$ product detectable. (d) Processing of Caspase 3 into the activated p20 poly-peptide. HL-60 cells were treated with saline (control) or increasing doses of $\mathrm{BR} \pm 800 \mu \mathrm{M}$ adenosine. $5 \mu \mathrm{M}$ and $10 \mu \mathrm{M}$ BR, which induce mainly apoptosis, trigger processing of caspase 3. $20 \mu \mathrm{M}$ and $40 \mu \mathrm{M}$ BR mainly provokes necrosis and this is also reflected by the reduced levels of activated caspase 3. In presence of adenosine also $20 \mu \mathrm{M}$ and $40 \mu \mathrm{M}$ BR activate caspase 3 and induce apoptosis. Equal sample loading was controlled by Ponceau S staining 
$\mathrm{a}$

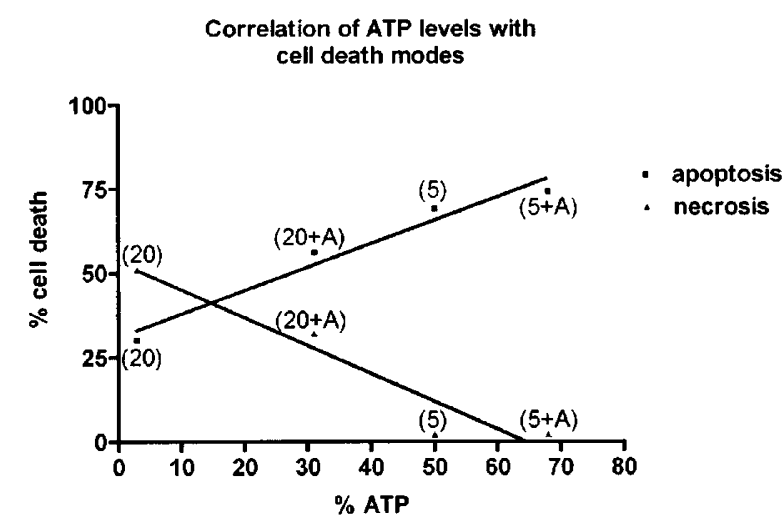

b

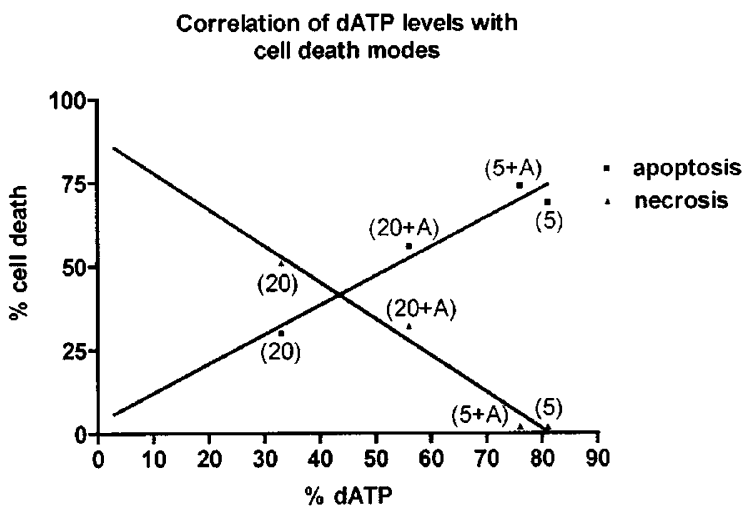

c

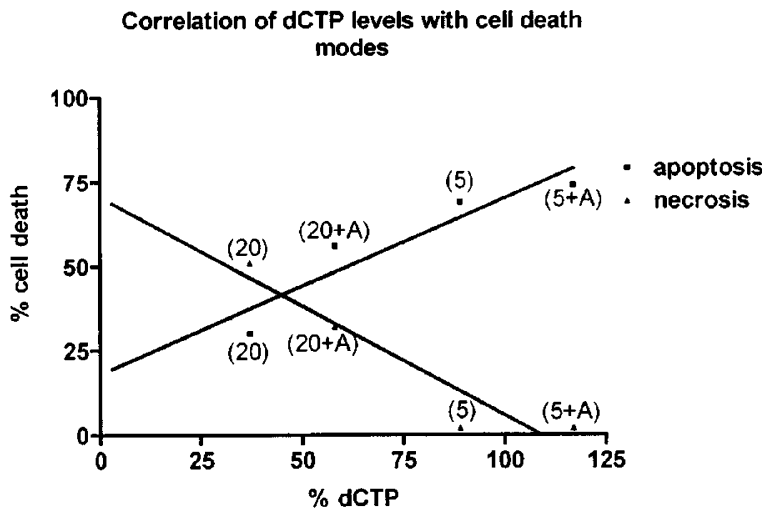

Figure 4 Correlation of nucleoside levels with cell death modes. HL-60 cells were treated with $5 \mu \mathrm{M}$ BR (5), $20 \mu \mathrm{M} \mathrm{BR}(20), \pm$ adenosine $(+\mathrm{A})$, for $16 \mathrm{~h}$, which was a time point when membranes were still intact and at which cell death modes are already determined, to measure ATP- (a), dATP- (b), and dCTP-levels (c), and for $48 \mathrm{~h}$ to analyze cell death modes. These graphs demonstrate, that ATP, dATP, and dCTP levels correlate directly with the percentages of apoptotic cells, whereas ATP, dATP and dCTP levels correlate indirectly with the percentages of necrotic cells

levels might result in less dGTP-mediated feedback stimulation of ADP reduction by ribonucleotide reductase $(R R)$. This in consequence decreases dADP levels and subsequently reduces dATP levels, which in fact was observed during treatment with BR. In turn, reduced dATP-
Treatment of HL-60 cells with cytotoxic drugs in combination with energy donors

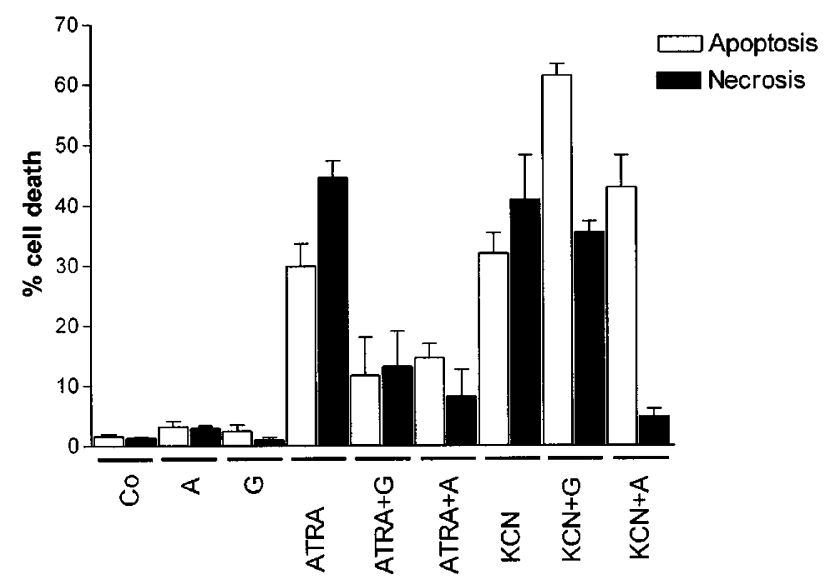

Figure 5 Modulations of cell deaths by adenosine and glucose. HL-60 cells were treated with saline (Co), $100 \mathrm{mM}$ glucose (G), $800 \mu \mathrm{M}$ adenosine (A), $120 \mu \mathrm{M}$ all-trans retinoic acid (ATRA), $20 \mathrm{mM}$ potassium cyanide (KCN) and combinations of ATRA or KCN with glucose and adenosine for $48 \mathrm{~h}$. Then the type of cell death was determined by HOPI double-staining. Statistical analysis by $t$-test confirmed that the differences between apoptosis- and necrosis-rates versus respective controls were significant $(P<0.05)$

mediated feedback inhibition of UDP-reduction by RR causes high dUDP and dUMP levels and this might be the reason for the observed increase in dTTP levels following BR treatment, because dUMP is the substrate for thymidylate synthase. Whereas there was no dose response correlation between ATP- and dATP-levels to total cell death, there was a direct correlation of these nucleotide pools to apoptosis and an indirect correlation to necrosis. Thus, ATP and/or dATP levels seem to determine cell death modes as it was previously suggested by others. ${ }^{15,24,25,39,42}$

In earlier investigations it was demonstrated that BR suppressed survival pathways, induced apoptosis-relevant genes $^{13,14}$ and activated Caspase 8 but not Caspase 9 (Polgar et al., submitted). However, only low doses of BR (5 and $10 \mu \mathrm{M})$, but not high doses $(20 \mu \mathrm{M}$ and more) induced apoptosis by a pathway that culminated in Caspase 3 activation. At high BR-concentrations the majority of cell death was by necrosis presumably due to massive DNA damage. DNA double-strand breaks became rapidly repaired but a substantial amount of single-strand breaks and/or alkali-labile sites remained non-repaired. Surprisingly adenosine enabled a substantial number of the $20 \mu \mathrm{M}$ BR-treated cells, which contained massive DNA damage $(23 \%)$, to escape necrosis and to undergo an apoptotic pathway (Table 2; Figure 6b). This percentage would correspond to cells with a DNA tail length between $>25 \mu \mathrm{m}$ and $<87 \mu \mathrm{m}$.

DNA repair processes consume energy, particularly PARP, which is an enzyme involved in DNA repair and that becomes activated in response to DNA strand breaks. ${ }^{43,44}$ PARP consumes NAD as a substrate ${ }^{45}$ and finally the cell depletes its ATP in an attempt to replenish its NAD pool. ${ }^{23,33,34,44,46}$ Thus, it is likely, that the necrotic 
Comet assay at neutral $\mathrm{pH}$

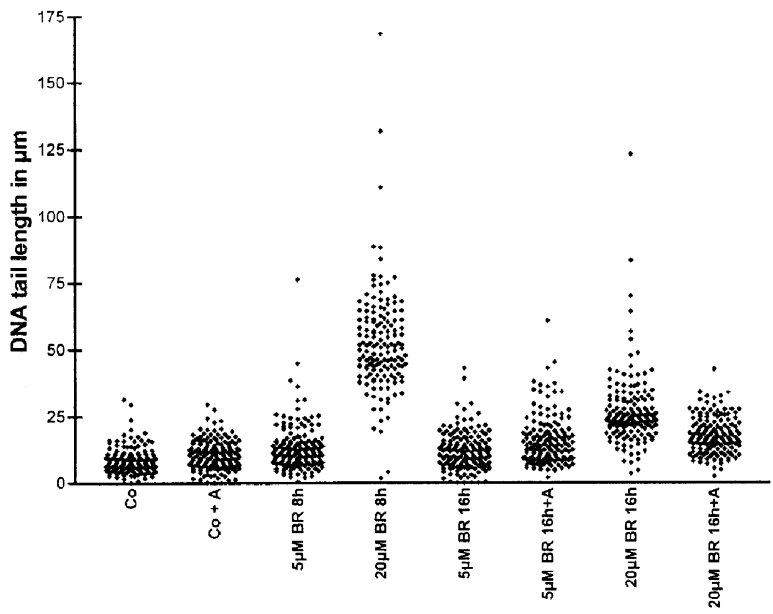

b

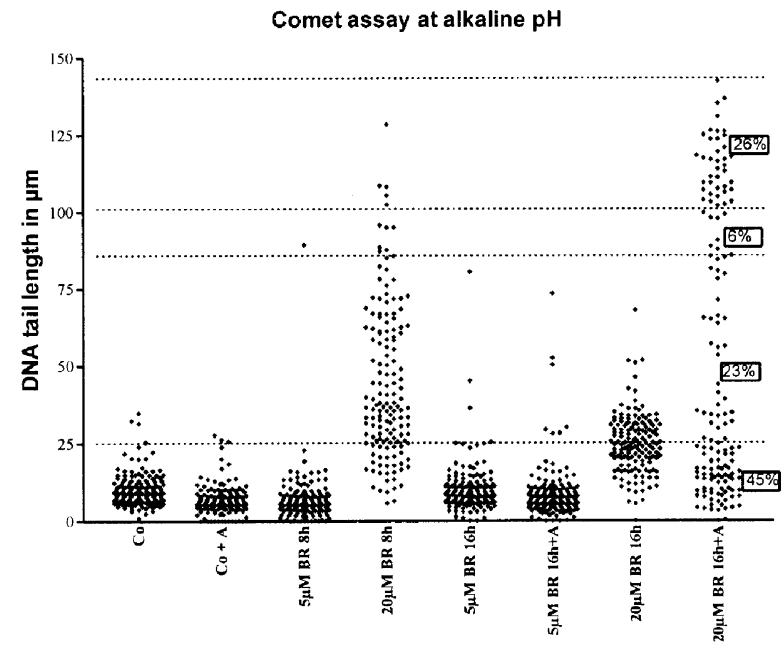

Figure 6 Induction of DNA damage in HL-60 cells by benzamide riboside (BR). Cells were treated with saline (Co), adenosine (Co+A), $5 \mu \mathrm{M}$, and $20 \mu \mathrm{M}$ $\mathrm{BR}, \pm$ adenosine, for 8 and $16 \mathrm{~h}$. Then cells were harvested for comet analysis at neutral (a) and alkaline (b) $\mathrm{pH}$ and the extent of DNA migration was measured as described in Materials and Methods. Per experimental point three cultures were made in parallel and from each culture 50 cells were evaluated. The figures show the distribution pattern of 150 cells. The values in rectangles (b) give the per cent of cells between the dotted lines, which were treated with $20 \mu \mathrm{M} \mathrm{BR}$ +adenosine. The observed differences in DNA tail length between $\mathrm{Co}_{0}$ and $20 \mu \mathrm{M}$ BR treatment for 8 and $16 \mathrm{~h} \pm$ adenosine, are significant under neutral and alkaline conditions

damage arising from high $B R$ concentrations are a consequence of DNA strand breaks and subsequent loss of ATP, which would have been required for an orchestrated apoptotic programme. Since maintenance of ATP by adenosine or supplementation with glucose, which is the major energy source of a cell, could prevent necrosis and favoured apoptosis, therefore, ATP and possibly also dATP are determinants of cell death modes.

This investigation supports the assumption, that energy donors can promote apoptosis and repress necrosis when

\section{Cell death modulation by $3-A B$}

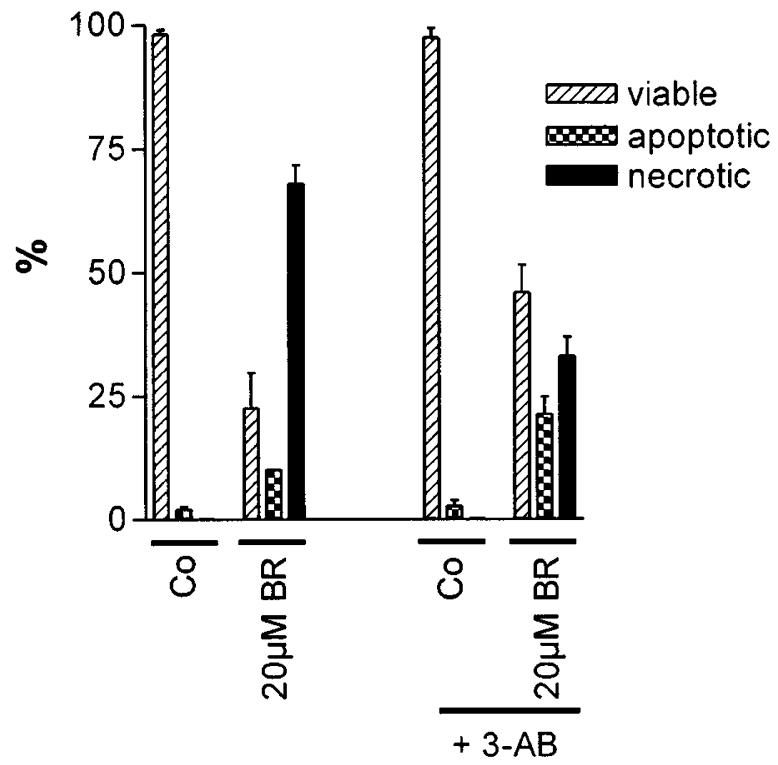

Figure 7 Prevention of necrosis by $3-A B$. HL-60 cells were treated with saline $\left(\mathrm{CO}_{0}\right)$ and $20 \mu \mathrm{M} B R,+3$-amino benzamide $(3-\mathrm{AB})$ for $48 \mathrm{~h}$. Then the cell status was analyzed by $\mathrm{HOPI}$ double-staining. The reduced necrosis rates after treatment with $20 \mu \mathrm{M} B \mathrm{~B}+3-\mathrm{AB}$ are significant $(P<0.05)$, whereas the increased apoptosis rates are not $(P=0.084)$

cell death is induced by various cytotoxic and therapeutic agents.

\section{Materials and Methods}

\section{Chemicals}

BR was synthesized as described earlier. ${ }^{1}$ Polyclonal Caspase 3 antibody was purchased from Research Diagnostics (Flanders, NJ, USA), adenosine, glucose, 3-amino benzamide (3-AB), all trans retinoic acid (ATRA) and cyanide $(K C N)$ were from Sigma (St. Louis, MO, USA).

\section{Cell culture}

The HL-60 human acute promyelocytic leukaemia cell line was from ATCC (Rockville, MD, USA). Cells were grown in RPMI 1640 medium (Gibco, Grand Island, NY, USA) with 10\% heat inactivated FCS (Boehringer Mannheim GmbH, Mannheim, Germany) and $2 \mathrm{mM} \mathrm{L-}$ Glutamine (Gibco, Gaithersburg, MD, USA) in humidified atmosphere with $5 \% \mathrm{CO}_{2}$ at $37^{\circ} \mathrm{C}$.

\section{Hoechst 33258 propidium iodide (HOPI) double-staining}

Hoechst 33258 (HO; Sigma) and propidium iodide (PI; Sigma) were added directly to the culture medium to final concentrations of $5 \mu \mathrm{g} / \mathrm{ml}$ and $2 \mu \mathrm{g} / \mathrm{ml}$, respectively. After an incubation period of $1 \mathrm{~h}$ at $37^{\circ} \mathrm{C}$, the cells were examined under a Zeiss Axiovert 35 fluorescence microscope with DAPI filters. Cells were photographed on Kodak 
Ektachrome P1600 film (Eastman Kodak Company, Rochester, NY, USA) and viable, apoptotic, and necrotic cells were counted manually. The Hoechst dye stains the nuclei of all cells and therefore allows to monitor nuclear changes associated with apoptosis, such as chromatin condensation and nuclear fragmentation (Figure 3c). PI, on the other hand, is excluded from viable and early apoptotic cells, consequently $\mathrm{PI}$ uptake indicates loss of membrane integrity characteristic of necrotic and late apoptotic cells. In combination with fluorescence microscopy, the selective uptake of the two dyes allows the monitoring of the induction of apoptosis in intact cultures and to distinguish it from non-apoptotic cell death (necrosis). Necrosis is characterised in this system by nuclear PI uptake without chromatin condensation or nuclear fragmentation.

\section{Electron microscopy}

For transmission electron microscopy (TEM) cells treated with PBS (controls), 5 or $20 \mu \mathrm{M}$ BR for $24 \mathrm{~h}$ were fixed with $2.5 \%$ glutaraldehyde (in $0.1 \mathrm{M}$ sodium cacodylate buffer with $4 \%$ sucrose, $\mathrm{pH} 7.2$ ) for $45 \mathrm{~min}$, washed in sodium cacodylate buffer and post-fixed in $2 \%$ osmium tetroxide (in $0.1 \mathrm{M}$ sodium cacodylate buffer with $4 \%$ sucrose) for $45 \mathrm{~min}$. Following several washes, the cells were concentrated by centrifugation at $150 \mathrm{~g}$ for $5 \mathrm{~min}$, dehydrated in a graded series of ethanol, washed in propylene oxide, embedded in Epon (Serva, Germany) and sectioned at about $70 \mathrm{~nm}$. The ultra-thin sections were stained with uranyl acetate/lead citrate for observation with a Zeiss EM 902 transmission electron microscope.

\section{ATP assay}

ATP content was measured with the ATP bioluminescence assay kit HS II from Boehringer Mannheim (Roche Molecular Biochemicals, Mannheim, Germany). Cells were treated with adenosine and BR for $16 \mathrm{~h}$, subsequently their viability was measured by Trypan blue exclusion. There were $<10 \%$ dead cells in each sample. 2.5 million cells were pelleted for each measurement and resuspended in $50 \mu$ dilution buffer. Equal amount of cell lysis reagent was then added and after an incubation period of $5 \mathrm{~min}$ at room temperature the samples were transferred to microtiter plates. Luciferase reagent $(100 \mu \mathrm{l})$ was added and the signal was detected immediately on a Lumi Imager F1 (Roche). Experiments were done in triplicates and the values of treated samples calculated as per cent of untreated controls.

\section{Western blots}

Cells from treated and untreated cultures were sedimented, washed in cold PBS, and lysed in SDS sample buffer (25 mM TRIS pH 6.8, 3\% SDS, $10 \%$ glycerol, $36 \mathrm{mM}$ DTT, $0.925 \mathrm{mM}$ EDTA). Equal amounts of protein (calculated with the Dot Metric Protein Assay Kit from Novus Molecular, San Diego, CA, USA) were loaded onto 10 or $15 \%$ polyacrylamide gels. Proteins were electrophoresed at $80 \mathrm{~V}$ for $2-3 \mathrm{~h}$ and then transblotted onto PVDF membranes (Hybond $\mathrm{P}$, Amersham International, UK) at $80 \mathrm{~V}$ for $2 \mathrm{~h}^{47}$ Membranes were quenched in PBS with $0.5 \%$ skim milk and $0.05 \%$ Tween 20 for $1 \mathrm{~h}$, incubated with primary antibodies (mouse monoclonal anti PARP C-2-10 used $1: 2000$, mouse monoclonal anti gelosin used 1:2000, Sigma; rabbit polyclonal anti caspase 3 antibody used 1:1000, Research Diagnostics) overnight at $4^{\circ} \mathrm{C}$ and with horse radish peroxidase conjugated secondary antibody for $2 \mathrm{~h}$ at room temperature. The ECL Kit (Amersham International, UK) was used for blot development, chemiluminescence was detected on Kodak Xomat UV films.

\section{Deoxyribonucleotide extraction and measurement}

dNTPs were extracted as described previously ${ }^{48}$ with trichloroacetic acid (TCA) $10 \%$ final concentration) followed by neutralization by trioctylamine and 1,1,2-trichlorotrifluoroethane $(1: 4)$ mixture. The TCA extract was dried using a Speedvac drying system at room temperature and, if necessary, stored at $-20^{\circ} \mathrm{C}$ until analysis. The assay for dNTP, which is based on the original DNA-polymerase assay, ${ }^{49}$ was optimized by the use of 96 -well plates ${ }^{50}$ and tailor-made oligonucleotides, ${ }^{51,52}$ and was performed as previously described for dCTP. ${ }^{48}$ After reconstitution of the samples in HEPES-buffered assay buffer $(\mathrm{pH} 7.3)$ at $10^{7}$ cells $/ \mathrm{ml}$, samples and standards $(0,1,2.5$ and 5 pmol dNTP) were added to diethylaminoethyl (DEAE) filter plates (Millipore, Ettenleur, The Netherlands). This was followed by addition of demi water (up to $30 \mu \mathrm{l}$ ) and $70 \mu \mathrm{l}$ of a reaction mix, consisting of $10 \mu \mathrm{l}\left[8^{3}{ }^{3} \mathrm{H}\right] \mathrm{dATP}(25 \mu \mathrm{M} ; 1.6 \mathrm{Ci} / \mathrm{mmol} ; 0.04 \mu \mathrm{Ci} / \mu \mathrm{l})$ for detection of dCTP, dTTP and dGTP and $10 \mu \mathrm{l}\left[\mathrm{CH}_{3}{ }^{3} \mathrm{H}\right] \mathrm{dTTP}(25 \mu \mathrm{M}, 1.6 \mathrm{Ci} / \mathrm{mmol}$, $0.04 \mu \mathrm{Ci} / \mu \mathrm{l})$ for dATP detection, $5 \mu \mathrm{l}$ appropriate oligonucleotide ( $6 \mu \mathrm{M}$, consisting of a primer attached to one of four possible templates specially designed for the detection of one of the four dNTPs), $5 \mu$ l Klenow DNA pol I and $50 \mu$ lassay buffer. The filterplates were gently vortexed and incubated at room temperature for $2 \mathrm{~h}$. The wells were washed, the wet filters punched out and radioactivity counted as described. ${ }^{48}$

\section{Comet assay and statistical analysis}

Neutral and alkaline single cell gel electrophoresis (SCGE) assays were carried out following the protocol described by Singh et al. ${ }^{53}$ To measure DNA double-strand breaks electrophoresis was carried out under neutral conditions at $\mathrm{pH} 7.5,{ }^{54}$ to analyze single-strand breaks the electrophoresis was carried out under alkaline conditions at $\mathrm{pH}$ $13.0 .{ }^{55} \mathrm{HL}-60$ cells were treated with $\mathrm{BR}$ and adenosine for $16 \mathrm{~h}$, then the viability of the cells was determined with Trypan blue. All cultures which were used for Comet analysis had a viability of $>90 \%$. Pellets obtained upon centrifugation were mixed with $100 \mu$ low melting agarose $\left(0.5 \%, 37^{\circ} \mathrm{C}\right)$ and spread on agarose coated slides according to Klaude et $a l^{56}$ Subsequently, the slides were exposed to lysis buffer ${ }^{53}$ and transferred to neutral and alkaline electrophoresis buffer respectively for $40 \mathrm{~min}$ to allow unwinding of DNA. Thereafter, electrophoresis was carried out for $40 \mathrm{~min}(300 \mathrm{~mA}, 25 \mathrm{~V})$ at $\mathrm{pH} 7.5$ and 13.0 respectively. Finally the slides were stained with ethidium bromide and evaluated under a fluorescence microscope (Nikon Model: 027012) with an automated image analysis system. ${ }^{57}$ For each experimental point, three cultures were evaluated and from each culture the tail lengths of 50 cells were determined. Statistically significant $(P<0.05)$ differences were determined with one way ANOVA. ${ }^{57}$

\section{Acknowledgements}

We wish to thank Anton Jäger for his excellent technical assistance in preparing the figures. Grant support: This work was supported in part by the Herzfelder'sche Familienstiftung, the AICR-grant No. 97-12, the Anton Dreher Memorial Foundation to $G$ Krupitza and by Austrian National Bank Fonds No. 8260 and the Hochschuljubiläumsfonds to T Szekeres.

\section{References}

1. Krohn K, Heins H and Wielckens K (1992) Synthesis and cytotoxic activity of Cglycosidic nicotinamide riboside analogues. J. Med. Chem. 35: 511-517 
2. Jayaram HN, Gharehbaghi K, Jayaram NR, Rieser J, Krohn K and Paull KD (1992) Cytotoxicity of a new IMP dehydrogenase inhibitor, benzamide riboside, to human myelogenous leukemia K562 cells. Biochem Biophys Res Commun 186: $1600-1606$

3. Gharehbaghi K, Sreenath A, Hao Z, Paull KD, Szekeres T, Cooney DA, Krohn K and Jayaram HN (1994) Comparison of biochemical parameters of benzamide riboside, a new inhibitor of IMP dehydrogenase, with tiazofurin and selenazofurin. Biochem. Pharmacol. 48: 1413-1419

4. Jackson RC, Weber G and Morris HP (1997) IMP dehydrogenase, an enzyme linked with proliferation and malignancy. Nature 256: 331-333

5. Weber G (1983) Biochemical strategy of cancer cells and the design of chemotherapy: G.H.A. Clowes Memorial Lecture. Cancer Res. 43: 3466-3492

6. Jayaram HN, Zhen W and Gharehbaghi K (1993) Biochemical consequences of resistance to tiazofurin in human myelogenous leukemic K562 cells. Cancer Res. 53: 2344-2348

7. Knight RD, Mangum J, Lucas DL, Cooney DA, Khan EC and Wright DG (1987) Inosine monophosphate dehydrogenase and myeloid cell maturation. Blood 69: $634-639$

8. Jayaram HN, Dion RL, Glazer RI, Johns DG, Robins RK, Srivastava PC and Cooney DA (1982) Initial studies on the mechanism of action of a new oncolytic thiazole nucleoside, 2-beta-D-ribofuranosylthiazole-4-carboxamide (NSC 286193). Biochem. Pharmacol. 31: 2371-2380

9. Tricot GJ, Jayaram HN, Lapis E, Natsumeda Y, Nichols CR, Kneebone P, Heerema N, Weber G and Hoffman R (1989) Biochemically directed therapy of leukemia with tiazofurin, a selective blocker of inosine $5^{\prime}$-phosphate dehydrogenase activity. Cancer Res. 49: 3696-3701

10. Wright DG, Boosalis MS, Waraska K, Oshry LJ, Weintraub LR and Vosburgh E (1996) Tiazofurin effects on IMP-dehydrogenase activity and expression in the leukemia cells of patients with CML blast crisis. Anticancer Res. 16: 3349-3351

11. Jayaram HN, Lapis E, Tricot G, Kneebone P, Paulik E, Zhen W, Engeler GP Hoffman R and Weber G (1992) Clinical pharmacokinetic study of tiazofurin administered as a 1-hour infusion. Int. J. Cancer 51: 182-188

12. Gharehbaghi K, Paull KD, Kelley JA, Barchi Jr JJ, Marquez VE, Cooney DA Monks A, Scudiero D, Krohn K and Jayaram HN (1994) Cytotoxicity and characterization of an active metabolite of benzamide riboside, a novel inhibitor of IMP dehydrogenase. Int. J. Cancer 56: 892-899

13. Jayaram HN, Cooney DA and Grusch M (1999) Consequences of IMP dehydrogenase inhibition, and its relationship to cancer and apoptosis. Curr. Med. Chem. 6: 561-574

14. Grusch M, Rosenberger G, Fuhrmann G, Braun K, Titscher B, Szekeres T Fritzer-Skekeres M, Oberhuber G, Krohn K, Hengstschlaeger M, Krupitza G and Jayaram HN (1999) Benzamide riboside induces apoptosis independent of Cdc25A expression in human ovarian carcinoma N.1 cells. Cell Death Differ. 6 : $736-744$

15. Tsujimoto $Y$ (1997) Apoptosis and necrosis: Intracellular ATP level as a determinant for cell death modes. Cell Death Differ. 4: 429-434

16. Nicotera $P$, Leist $M$ and Ferrando-May $E$ (1998) Intracellular ATP, a switch in the decision between apoptosis and necrosis. Toxicol. Lett. 102: 139-142

17. Formigli L, Papucci L, Tani A, Schiavone N, Tempestini A, Orlandini GE Capaccioli S and Orlandini SZ (2000) Aponecrosis: morphological and biochemical exploration of a syncretic process of cell death sharing apoptosis and necrosis. J. Cell. Physiol. 182: $41-49$

18. Leist M and Nicotera P (1997) The shape of cell death. Biochem. Biophys. Res. Commun. 236: 1-9

19. Samali A, Nordgren H, Zhivotovsky B, Peterson E and Orrenius S (1999) A comparative study of apoptosis and necrosis in HepG2 cells: oxidant-induced caspase inactivation leads to necrosis. Biochem. Biophys. Res. Commun. 255: $6-11$

20. Rosenberger G, Fuhrmann G, Grusch M, FassI S, Elford HL, Smid K, Peters GJ, Szekeres T and Krupitza G (2000) The ribonucleotide reductase inhibitor trimidox induces c-myc and apoptosis of human ovarian carcinoma cells. Life Sci. 67: $3131-3142$

21. Kothakota S, Azuma T, Reinhard C, Klippel A, Tang J, Chu K, McGarry TJ, Kirschner MW, Koths K, Kwiatkowski DJ and Williams LT (1997) Caspase-3generated fragment of gelsolin: effector of morphological change in apoptosis. Science 278: 294-298

22. Grusch M, Fritzer-Szekeres M, Fuhrmann G, Rosenberger G, Luxbacher C, Elford HL, Smid K, Peters GJ, Szekeres T and Krupitza G (2001) Activation of caspases and induction of apoptosis by amidox and didox. Exp. Hematol. in press
23. Ha HC and Snyder SH (1999) Poly(ADP-ribose) polymerase is a mediator of necrotic cell death by ATP depletion. Proc. Natl. Acad. Sci. USA 96: 1397813982

24. Nicotera P and Leist M (1997) Energy supply and the shape of death in neurons and lymphoid cells. Cell Death Differ. 4: 435-442

25. Leist M, Single B, Castoldi AF, Kuhnle S and Nicotera P (1997) Intracellular adenosine triphosphate (ATP) concentration: a switch in the decision between apoptosis and necrosis. J. Exp. Med. 185: 1481-1486

26. Leist M, Single B, Naumann H, Fava E, Simon B, Kuhnle S and Nicotera P (1999) Inhibition of mitochondrial ATP generation by nitric oxide switches apoptosis to necrosis. Exp. Cell. Res. 249: 396-403

27. Petronini PG, Urbani S, Alfieri R, Borghetti AF and Guidotti GG (1996) Cell susceptibility to apoptosis by glutamine deprivation and rescue: survival and apoptotic death in cultured lymphoma-leukemia cell lines. J. Cell. Physiol. 169: $175-185$

28. Fritzer-Szekeres M, Grusch M, Luxbacher C, Horvath S, Krupitza G, Elford HL and Szekeres T (2000) Trimidox, an inhibitor of ribonucleotide reductase, induces apoptosis and activates caspases in $\mathrm{HL}-60$ promyelocytic leukemia cells. Exp. Hematol. 28: 924-930

29. Castaigne S, Chomienne C, Daniel MT, Ballerini P, Berger R, Fenaux P and Degos L (1990) All-trans retinoic acid as a differentiation therapy for acute promyelocytic leukemia. I. Clinical results. Blood 76: 1704-1709

30. Fernandez PA, Rotello RJ, Rangini Z, Doupe A, Drexler HC and Yuan J (1994) Expression of a specific marker of avian programmed cell death in both apoptosis and necrosis. Proc. Natl. Acad. Sci. USA 91: $8641-8645$

31. Nicotera $\mathrm{P}$, Thor $\mathrm{H}$ and Orrenius $\mathrm{S}$ (1989) Cytosolic-free $\mathrm{Ca2}+$ and cell killing in hepatoma 1c1c7 cells exposed to chemical anoxia. FASEB J. 3: 59-64

32. Shimizu S, Eguchi $Y$, Kamiike W, Waguri S, Uchiyama $Y$, Matsuda $H$ and Tsujimoto $Y$ (1996) Bcl-2 blocks loss of mitochondrial membrane potential while ICE inhibitors act at a different step during inhibition of death induced by respiratory chain inhibitors. Oncogene 13: $21-29$

33. Lee YJ and Shacter E (1999) Oxidative stress inhibits apoptosis in human lymphoma cells. J. Biol. Chem. 274: 19792-19798

34. Filipovic DM, Meng X and Reeves WB (1999) Inhibition of PARP prevents oxidant-induced necrosis but not apoptosis in LLC-PK1 cells. Am. J. Physiol. 277: F428-436

35. Kim JW, Won J, Sohn Sand Joe CO (2000) DNA-binding activity of the N-terminal cleavage product of poly(ADP-ribose) polymerase is required for UV mediated apoptosis. J. Cell. Sci. 113: 955-961

36. Watson AJ, Askew JN and Benson RS (1995) Poly(adenosine diphosphate ribose) polymerase inhibition prevents necrosis induced by $\mathrm{H} 2 \mathrm{O} 2$ but not apoptosis. Gastroenterology 109: 472-482

37. Eliasson MJ, Sampei K, Mandir AS, Hurn PD, Traystman RJ, Bao J, Pieper A, Wang ZQ, Dawson TM, Snyder SH and Dawson VL (1997) Poly(ADP-ribose) polymerase gene disruption renders mice resistant to cerebral ischemia. Nat. Med. 3: $1089-1095$

38. Finstad HS, Kolset SO, Holme JA, Wiger R, Farrants AK, Blomhoff R and Drevon CA (1994) Effect of $n-3$ and n-6 fatty acids on proliferation and differentiation of promyelocytic leukemic HL-60 cells. Blood 84: 3799-3809

39. Eguchi Y, Shimizu S and Tsujimoto Y (1997) Intracellular ATP levels determine cell death fate by apoptosis or necrosis. Cancer Res. 57: 1835-1840

40. Hunakova L, Duraj J, Romanova D, Novotny L, SedlakJ, Kelley MR, Szekeres T, Jayaram HN and Chorvath B (1998) Staurosporine enhanced benazmide riboside-induced apoptosis in human multidrug-resistant promyelocytic leukemia cells (HL-60/VCR) in vitro. Neoplasma 45: 204-209

41. Vitale M, Zamai L, Mazzotti G, Cataldi A and Falcieri E (1993) Differential kinetics of propidium iodide uptake in apoptotic and necrotic thymocytes. Histochemistry 100: $223-229$

42. Lieberthal W, Menza SA and Levine JS (1998) Graded ATP depletion can cause necrosis or apoptosis of cultured mouse proximal tubular cells. Am. J. Physiol. 274: F315-327.

43. Juarez-Salinas H, Sims JL and Jacobson MK (1979) Poly(ADP-ribose) levels in carcinogen-treated cells. Nature 282: 740-741

44. Wielckens K, Schmidt A, George E, Bredehorst R and Hilz H (1982) DNA fragmentation and NAD depletion. Their relation to the turnover of endogenous mono(ADP-ribosyl) and poly(ADP-ribosyl) proteins. J. Biol. Chem. 257: 12872 12877

45. Ueda K and Hayaishi O (1985) ADP-ribosylation. Annu. Rev. Biochem. 54: $73-$ 100 
46. Althaus FR and Richter C (1987) ADP-ribosylation of proteins. Enzymology and biological significance. Mol. Biol. Biochem. Biophys. 37: 1-237

47. Towbin H, Staehelin T and Gordon J (1979) Electrophoretic transfer of proteins from polyacrylamide gels to nitrocellulose sheets: procedure and some applications. Proc. Natl. Acad. Sci. USA 76: 4350-4354

48. van Moorsel CJ, Pinedo HM, Veerman G, Guechev A, Smid K, Loves WJ Vermorken JB, Postmus PE and Peters GJ (1999) Combination chemotherapy studies with gemcitabine and etoposide in non-small cell lung and ovarian cancer cell lines. Biochem. Pharmacol. 57: 407-415

49. Hunting D and Henderson JF (1981) Determination of deoxyribonucleoside triphosphates using DNA polymerase: a critical evaluation. Can. J. Biochem. 59: 723-727

50. Peters GJ, De Abreu RA, Oosterhof A and VeerkampJH (1983) Concentration of nucleotides and deoxynucleotides in peripheral and phytohemagglutininstimulated mammaliam lymphocytes. Effects of adenosine and deoxyadenosine. Biochim. Biophys. Acta 759: 7-15

51. Sherman PA and Fyfe JA (1989) Enzymatic assay for deoxyribonucleoside triphosphates using synthetic oligonucleotides as template primers. Anal. Biochem. 180: 222-226
52. Iwasaki H, Huang P, Keating MJ and PlunkettW (1997) Differential incorporation of ara-C, gemcitabine, and fludarabine into replicating and repairing DNA in proliferating human leukemia cells. Blood 90: 270-278

53. Singh NP, McCoy MT, Tice RR and Schneider EL (1988) A simple technique for quantitation of low levels of DNA damage in individual cells. Exp. Cell Res. 175: $184-191$

54. Olive PL, Wlodek D and Banath JP (1991) DNA double-strand breaks measured in individual cells subjected to gel electrophoresis. Cancer Res. 51: 4671-4676

55. Tice RR and Strauss GH (1995) The single cell gel electrophoresis/cometassay: a potential tool for detecting radiation-induced DNA damage in humans. Stem Cells 13 Suppl 1: 207-214

56. Klaude M, Eriksson S, Nygren J and Ahnstrom G (1996) The comet assay: mechanisms and technical considerations. Mutat. Res. 363: 89-96

57. Uhl M, Helma C and Knasmuller S (2000) Evaluation of the single cell gel electrophoresis assay with human hepatoma (Hep G2) cells. Mutat. Res. 468: 213-225 